\title{
IMPLEMENTASI KEBIJAKAN PENYELENGGARAAN PENDIDIKAN INKLUSIF
}

\author{
Zaini Sudarto \\ Prodi Pendidikan Luar Biasa FIP Unesa \\ E-mail: zainisudarto@gmail.com
}

\begin{abstract}
Abstrak
Pendidikan inklusif adalah sistem penyelenggaraan pendidikan yang memberikan kesempatan kepada semua peserta didik berkebutuhan khusus untuk dapat mengikuti pendidikan atau pembelajaran dalam lingkungan pendidikan secara bersama-sama dengan peserta didik pada umumnya (Pergub Jatim, Nomor 6 Tahun 2011).

Dalam pelaksanaan implementasi kebijakan penyelenggaraan pendidikan inklusif di enam Sekolah Penyelenggara Inklusif jenjang SDN dan SMPN, ditemukan beberapa masalah klasik yaitu kurangnya tenaga guru Pendidik Khusus (GPK), tidak tersedianya ruang khusus untuk penanganan Anak Berkebutuhan Khusus (ABK), tidak ada tenaga psikolog atau Bimbingan Konseling (BK), kurangnya sosialisasi tentang pendidikan inklusif di masyarakat sekitar sekolah, dan kurangnya pengetahuan guru reguler tentang $\mathrm{ABK}$.

Tujuan penelitian ini adalah untuk mendeskripsikan implementasi kebijakan Pemerintah tentang pendidikan inklusif di jenjang Sekolah Dasar dan jenjang Sekolah Menengah Pertama. Jenis penelitian yang digunakan adalah penelitian deskriptif dengan pendekatan kualitatif. Fokus penelitian pada pelaksanaan atau implementasi penyelenggaraan pendidikan inklusif dengan menggunakan teori Merile S. Grindle, sedangkan pengumpulan data digunakan teknik observasi, wawancara, dokumentasi dan triangulasi.

Berdasarkan hasil penelitian yang ditinjau dari variabel isi kebijakan dari Peraturan Gubernur Jawa Timur Nomor 6 Tahun 2011 telah memenuhi semua kepentingan peserta didik Anak Berkebutuhan Khusus. Adanya program penyelenggaraan Pendidikan Inklusif manfaatnya dirasakan oleh semua orang tua anak berkebutuhan khusus, target perubahan dari Peraturan Gubernur Jawa Timur perlu ditingkatkan terutama pada segi implementor kebijakan, sumber daya manusia untuk Tenaga Guru Pendidik Khusus, tenaga Bimbingan Konseling (BK), dan tenaga terapis yang belum belum dialokasikan.

Adapun saran peneliti, diharapkan para pelaksana kebijakan terus melakukan pembinaan atau pelatihan kepada guru reguler mengenai penyelenggaraan pendidikan inklusif, melakukan sosialisasi kepada masyarakat terkait dengan penyelenggaraan pendidikan inklusif, perlu dialokasikan lagi tenaga guru pendidik khusus serta guru BK dan tenaga terapis untuk bermitra dengan Guru Pendidik Khusus (GPK) dalam penyelenggaraan pendidikan inklusif.
\end{abstract}

Kata Kunci : Implementasi Kebijakan, Penyelenggaraan Pendidikan Inklusif.

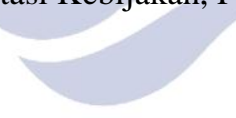

Abstract

Inclusive education is to provide education system that provides opportunities for all learners with special needs to be able to follow education or learning in an educational setting together with the learners in general (East Java Governor Regulation, No. 6 of 2011).

In the implementation of policy implementation implementation of inclusive education in six schools Organising Inclusive Level Elementary School and Junior High School, was found several classical problems, namely a lack of teachers Educators Lodging, unavailability of dedicated space for the handling of Children with Special Needs, no psychologists or guidance counseling, lack of socialization on inclusive education in the community around the school, and lack of knowledge about of Children with Special Needs regular teachers.

The purpose of this study was to describe the implementation of the Government policy of inclusive education at the level of elementary and junior high school levels. This type of research is descriptive research with a qualitative approach. The focus of research on the implementation or operation of the implementation of inclusive education by using the theory Merile S. Grindle, while the data collection used observation, interview, documentation and triangulation.

Based on the research results in terms of policy content variable from East Java Governor Regulation No. 6 of 2011 has fulfilled all interests of learners Children with Special Needs. Their program for implementation of inclusive education benefits felt by all parents of children with special needs, the target of a change of Rule Governor of East Java needs to be improved, especially in terms of the implementor of policies, human resources for the Power Master Educators Special, power Counseling, and therapist not yet allocated.

Keywords: Policy Implementation, Implementation of Inclusive Education. 


\section{PENDAHULUAN}

Pembahasan tentang mutu pendidikan di Indonesia, tidak dapat dipungkiri bahwa pendidikan bagi Anak Berkebutuhan Khusus di In donesia hingga saat ini kurang diperhatikan dan belum bisa ditangani secara maksimal. Anak berkebutuhan khusus memang berbeda dengan anak normal pada umumnya, baik dari segi fisik, mental, intelektual maupun sosialnya. Sebagai warga negara, anak berkebutuhan khusus (ABK) memiliki hak dan kuwajiban yang sama sebagai warga negara serta memiliki kesamaan perlakuan, termasuk dalam memperoleh pendidikan.

Mengingat pendidikan merupakan salah satu modal utama untuk semua anak, anak berkebutuhan khusus-pun juga membutuhkan pendidikan sebagai bekal hidup mandiri di masyaarakat. Mereka tidak membutuhkan uluran tangan atau belas kasihan, tetapi mereka butuh pengertian dari berbagai fihak untuk bereksistensi di tengah kehidupan masyarakat. Sampai saat ini keberadaan ABK dilingkungan masyarakat masih banyak yang mengganggap anak berkebutuhan khusus sebagai orang yang tak layak masuk dalam ruang publik (Suharto, 2009). Sisi lain, sebagian besar masyarakat dan orang tua masih kurang berperan aktif dalam perkembangan pendidikan anaknya yang mendapat lebel ABK, sehingga berdampak terhadap rendahnya mutu pendidikan pada anak berkubutuhan khusus.

Esensi pendidikan inklusif adalah salah satu upaya peningkatan mutu pelayanan pendidikan pada anak berkebutuhan khusus (ABK) yang tidak membedabedakan antara anak berkebutuhan khusus dengan anak normal pada umumnya. Sejak tahun 2009 Pemerintah Indonesia telah mengintruksikan kepada lembaga pendidikan disemua jenjang melaksanakan Pendidikan berbasis Inklusif. Dengan demikian, konsekwensi logis yang harus diterima adalah semua implementator di lembaga pendidikan harus menerima semua peserta didik tanpa terkecuali, termasuk peserta didik yang mengalami hambatan phisik, psikis, perilaku dan spiko sosialnya di sekolah-sekolah reguler yang biasanya dimasuki anakanak non berkebutuhan khusus atau reguler (Ormrod, 2008).

Pendidikan inklusif merupakan paradikma baru yang bertujuan untuk pemenuhan hak azasi manusia atas pendidikan tanpa adanya diskriminasi, dengan memberi kesempatan pendidikan yang berkualitas kepada semua anak tanpa perkecualian, sehingga semua anak memiliki kesempatan yang sama untuk secara aktif mengembangkan potensi pribadinya dalam lingkungan yang sama.

Dalam konteks yang lebih luas, pendidikan inklusi dapat dimaknai sebagai education for all, merupakan salah satu bentuk reformasi dalam dunia pendidikan yang menekankan sikap anti diskriminasi, perjuangan persamaan hak dan kesempatan, keadilan, dan perluasan akses pendidikan bagi semua, peningkatan mutu pendidikan, upaya strategis dalam menuntaskan wajib belajar 9 tahun, serta upaya merubah sikap masyarakat terhadap anak berkebutuhan khusus.

berdasarkan Peraturan Menteri Pendidikan Nasional RI nomor 7 tahun 2009 tentang Pendidikan Inklusif, Pemerintah Provinsi Jawa Timur telah menyikapi dengan mengeluarkan kebijakan, melalui Peraturan Gubernur Jawa Timur Nomor 6 Tahun 2011 tentang Penyelenggaraan Pendidikan Inklusif sudah dilaksanakan di Propinsi Jawa Timur. Menurut data dari Dinas Pendidikan dan Kebudayaan Kota Surabaya, pada tahun 2013 terdapat 2.796 anak berkebutuhan khusus yang tersebar diberbagai wilayah.

Adapun lembaga pendidikan yang telah melaksanakan program inklusi di wilayah Surabaya, 50 lembaga untuk jenjang 50 SD Negeri, 10 SMP Negeri, 2 SMA Negeri, dan 2 SMK Negeri (www.ppdbsurabaya.net). Hal ini menunjukkan bahwa pemerintah Kota Surabaya dan Dinas Pendidikan Kota Surabaya ingin memperbaiki kualitas pendidikan dan memberikan pelayanan terbaik bagi anak berkebutuhan khusus dalam pendidikan terpadu yang mengintegrasikan anak berkebutuhan khusus masuk ke sekolah reguler, sebagai landasan pendidikan yang tidak membedakan keragaman karakteristik individu. Dengan hadirnya pendidikan inklusif maka hak-hak anak berkebutuhan khusus diharapkan memperoleh pendidikan yang layak.

Selanjutnya dalam peraturan tersebut juga dijelaskan tujuan dari dibuatnya program pendidikan inklusif ini untuk memberikan kesempatan yang seluasluasnya kepada semua peserta didik mulai dari sekolah dasar sampai sekolah menengah yang memiliki kelainan fisik, emosional, mental, dan sosial atau memiliki potensi kecerdasan dan/atau bakat istimewa yang meliputi tuna netra, tuna rungu, tuna wicara, tuna grahita ringan, tuna daksa, anak dengan gangguan emosional, berkesulitan belajar, autis, untuk memperoleh pendidikan yang bermutu sesuai dengan kebutuhan dan kemampuannya, serta mewujudkan penyelenggaraan pendidikan yang menghargai keanekaragaman, dan tidak diskriminatif bagi semua peserta didik berkebutuhan khusus.

Pada umumnya sistem Pembelajaran pendidikan inklusif di jenjang Sekolah Dasar dan Sekolah menengah menerapkan pendekatan model inklusif (full inclusive), dimana peserta didik berkebutuhan khusus belajar bersama-sama dengan peserta didik pada umumnya dalam kelas yang sama. Kurikulum yang digunakan yaitu 
Kurikulum modifikasi, yang merupakan hasil dari penyesuaian kurikulum standar satuan pendidikan dengan kemampuan peserta didik berkebutuhan khusus. Peserta didik berkebutuhan khusus membutuhkan modifikasi kurikulum yang disesuaikan dengan kebutuhan berdasarkan kondisi khusus yang dimilikinya.

Secara administatif proses modifikasi kurikulum terlihat dalam silabus dan Rancangan Proses Pembelajaran (RPP) yang digunakan. Bagi peserta didik yang membutuhkan layanan individual, proses modifikasi kurikulum terlihat dalam Program Pembelajaran Individual (PPI). Peserta didik berkebutuhan khusus dapat mengikuti proses pembelajaran secara khusus di ruang sumber/ruang pintar yang ditangani oleh Guru Pendidik Khusus (GPK) berdasarkan karakteristik permasalahan ABK, termasuk di dalamnya adalah program pembelajaran kompensatoris. Keberadaan ruang sumber harus digunakan sebagai tempat pembelajaran individual dan bukan sebagai ruang untuk menempatkan peserta didik berkebutuhan khusus sepanjang waktu. Pendekatan model pembelajaran inklusif penuh diharapkan mampu memberikan peran dan perkembangan bagi kemajuan peserta didik berkebutuhan khusus yang meliputi perkembangan fisik, mental, intelektual, dan sosial.

berbagai permasalahan yang terjadi dalam
penyelenggaraan pendidikan inklusif, pertama, jumlah keseluruhan (3 SD dan 3 SMP) peserta didik anak berkebutuhan khusus sebanyak 68 siswa tidak sebanding dengan jumlah tenaga guru pendidik khusus, yaitu hanya ada satu orang yang tersedia dimasing-masing sekolah. Dengan adanya permasalahan tersebut maka proses pelayanan program pendidikan inklusif yang diberikan kepada anak berkebutuhan khusus kurang maksimal, sehingga perlu ditambah lagi tenaga guru pendidik khusus yang memiliki spesifikasi guru dibidang Pendidikan Luar Biasa agar pelayanan terhadap anak berkebutuhan khusus dapat dilayanani secara maksimal. Kedua, tidak ada tenaga Bimbingan Konseling, dan yang ketiga tidak ada tenaga terapis, sehingga guru pendidik khusus merangkap tugas menjadi tenaga Bimbingan Konseling (BK) dan tenaga terapis.

Berawal dari fenomena permasalahan diatas maka peneliti tertarik untuk mengkaji lebih dalam implementasi program pendidikan inklusif berdasarkan Peraturan Gubernur Jawa Timur Nomor 6 Tahun 2011 tentang Penyelenggaraan Pendidikan Inklusif di Surabaya. Untuk mengukur keberhasilan suatu implementasi kebijakan publik, maka penelitian ini akan dianalisis dengan menggunakan model implementasi dari Merilee S. Grindle yang dipengaruhi oleh dua variabel besar, yaitu isi kebijakan (content of policy) dan lingkungan implementasi (context of implementation). Kedua variabel tersebut terdapat beberapa aspek penting untuk mengukur suatu keberhasilan implementasi.

Variabel isi kebijakan terdapat enam aspek penting, yaitu kepentingan kelompok sasaran; tipe manfaat, derajat perubahan yang diinginkan; letak pengambilan keputusan; pelaksanaan program; dan sumber daya yang dilibatkan. Kemudian yang kedua variabel lingkungan implementasi terdapat tiga aspek penting, yaitu kekuasaan, kepentingan, dan strategi dari penentu kebijakan; karakteristik lembaga dan penguasa; kepatuhan dan daya tanggap. Teori model implementasi dari Merilee S. Grindle ini dianggap relevan dalam proses penganalisaan untuk penelitian dengan pendekatan kualitatif.

Berdasarkan latar belakang masalah yang telah dipaparkan, maka rumusan masalah dalam penelitian ini adalah"Bagaimana Implementasi Program Pendidikan Inklusif?". Sesuai dengan latar belakang dan rumusan masalah, maka tujuan dari penelitian ini adalah untuk mendeskripsikan Implementasi Program Pendidikan Inklusif di tiga Sekolah Dasar Negeri dan tiga Sekolah Menengah Petama Negeri yang telah melaksanakan Program Pendidikan Inklusif di kota Surabaya.

\section{METODE}

Jenis penelitian ini adalah penelitian deskripstif dengan menggunakan pendekatan kualitatif. Penelitian ini mengambil fokus dari Keberhasilan implementasi menurut Merilee S. Grindle ( 1980 ) dipengaruhi oleh dua variabel besar, yakni isi kebijakan pemerintah dan lingkungan implementasi pelaksanaan pendidikan inklusif.

PENGUMPULAN DATA MENGGUNAKAN SUMBER PRIMER DAN SUMBER SEKUNDER. SUMBER DATA PRIMER DIPEROLEH DARI SUMBER ASLINYA MELALUI NARA SUMBER YANG TEPAT dan dijadikan responden dalam penelitian. Sumber data primer yang digunakan yaitu enam nara sumber selaku Koordinator inklusi, enam Guru reguler, enam guru GPK, dan enam Wali Murid ABK. Sumber data sekunder merupakan sumber yang tidak langsung memberikan data kepada pengumpul data melalui dokumen.

Teknik pengambilan sampel yang digunakan ada dua yaitu, teknik purposive sampling dan snowball sampling. Dalam hal ini Koordinator inklusif, Guru Mata Pelajaran, Guru pendidik khusus, Sedangkan Wali murid berkebutuhan khusus yang akan dijadikan sebagai nara sumber penelitian dipilih secara acak dengan menggunakan teknik snowball sampling. Teknik Pengumpulan Data yang menggunakan wawancara, observasi, dokumentasi dan triangulasi. Teknik analisis data pada penelitian ini menggunakan analisis data model 
interaktif dari Miles dan Huberman dengan langkahlangkah Reduksi data, penyajian data, penarikan kesimpulan dan verifikasi.

\section{HASIL DAN PEMBAHASAN}

Implementasi Program Pendidikan Inklusif di Surabaya dalam penelitian ini dapat dikaji berdasarkan dua variabel besar yaitu, variabel isi kebijakan dan variabel lingkungan Implementasi menurut Merlie S Grindle. Variabel isi kebijakan mencakup beberapa sub variabel;

Pertama, "kepentingan kelompok sasaran"

Peraturan Gubernur Jawa Timur Nomor 6 Tahun 2011 tentang Penyelenggaraan Pendidikan Inklusif merupakan sebuah kebijakan yang digunakan dalam melaksanakan program pendidikan inklusif. Latar belakang dibentuknya Peraturan Gubernur Jawa Timur Nomor 6 Tahun 2011 tentang Penyelenggaraan Pendidikan Inklusif, bahwa dalam Peraturan Menteri Pendidikan Nasional RI Nomor 7 Tahun 2009 tentang Pendidikan Inklusif Pasal 6 menyatakan bahwa (1) Pemerintah Kabupaten/Kota menjamin terselenggaranya pendidikan inklusif sesuai dengan kebutuhan peserta didik (2) Pemerintah Kabupaten/Kota menjamin tersedianya sumber daya pendidikan inklusif pada satuan pendidikan yang ditunjuk (3) Pemerintah dan Pemerintah Provinsi membantu tersedianya sumber daya pendidikan inklusif. Supaya program pendidikan inklusif dapat terlaksana sesuai dengan tujuan dan dapat dirasakan oleh semua anak berkebutuhan khusus di Provinsi Jawa Timur, maka perlu mengatur Penyelenggaraan Pendidikan Inklusif di Provinsi Jawa Timur dengan Peraturan Gubernur Jawa Timur.

Peraturan Gubernur Jawa Timur Nomor 6 Tahun 2011 tentang Penyelenggaraan Pendidikan Inklusif merupakan kebijakan yang mengatur sistem penyelenggaraan pendidikan yang memberikan kesempatan kepada semua peserta didik yang memiliki kelainan dan memiliki potensi kecerdasan atau bakat istimewa untuk mengikuti pendidikan atau pembelajaran dalam lingkungan pendidikan secara bersama-sama dengan peserta didik pada umumnya. Hal ini menunjukkan bahwa pemerintah Kota Surabaya dan Dinas Pendidikan dan Kebudayaan Kota Surabaya ingin memperbaiki kualitas mutu pendidikan dan memberikan pelayanan pendidikan inklusif bagi anak berkebutuhan khusus.

Dengan diterbitkannya Peraturan Gubernur Jawa Timur Nomor 6 Tahun 2011 diharapkan mampu melayani semua kepentingan yang dibutuhkan peserta didik berkebutuhan khusus yaitu untuk memberikan layanan pendidikan yang bermutu sesuai dengan hambatan yang dimiliki anak berkebutuhan khusus untuk belajar bersama-sama dengan siswa reguler serta dapat bersosialisasi dengan lingkungan disekitarnya dan menciptakan pendidikan yang non dikriminatif. Yang terpenting dalam pelayanan ABK memberikan pelayanan kompensatoris dan terapi agar bisa hidup secara mandiri sebagai bekal hidup ditengah masyarakat seperti layaknya mereka yang normal.

Dengan demikian, kebijakan Peraturan Gubernur Jawa Timur Nomor 6 Tahun 2011 memenuhi semua kepentingan yang dibutuhkan target groupnya untuk memperoleh layanan pendidikan yang layak sesuai dengan hambatan masing-masing dan dapat bersosialisasi, hidup mandiri, serta menciptakan pendidikan yang tidak diskriminasi.

Kedua,"tipe manfaat"

Peraturan Gubernur Jawa Timur Nomor 6 Tahun 2011 sebagai bentuk komitmen Pemerintah Provinsi Jawa Timur untuk menjamin penyelenggaraan pendidikan inklusif di Jawa Timur, dalam rangka memperluas pemerataan dan akses pendidikan bagi peserta didik usia sekolah, baik laki-laki maupun perempuan yang belum terlayani untuk memiliki kesempatan mendapatkan layanan pendidikan melalui pendidikan inklusif bagi anak peserta didik yang berkebutuhan khusus terutama untuk daerah-daerah yang tidak tersedia layanan pendidikan khusus atau luar biasa.

Setelah dibentuknya Peraturan Gubernur Jawa Timur Nomor 6 Tahun 2011 Tentang Penyelenggaran Pendidikan Inklusif, maka manfaat dari kebijakan ini adalah untuk memberikan pelayanan secara maksimal kepada semua peserta didik berkebutuhan khusus dalam dunia pendidikan dengan tanpa adanya diskriminasi. Diskriminasi yang dimaksudkan antara lain pembedaan atas dasar gender, agama, etnis, status sosial, kemampuan ekonomi, dan kondisi fisik atau mental anak.

Selain itu juga dengan adanya peraturan ini dapat memberikan manfaat kepada peserta didik berkebutuhan khusus agar bisa hidup secara mandiri dan dapat bersosialisasi dengan peserta didik pada umumnya. Jadi, manfaat yang diterima dari diterbitkannya Peraturan Gubernur Jawa Timur Nomor 6 Tahun 2011 tentang Penyelenggaraan Pendidikan Inklusif adalah agar peserta didik berkebutuhan khusus dapat bersosialisasi dengan peserta didik pada umumnya, serta dapat menambah pengetahuan atau wawasan siswa berkebutuhan kebutuhan. jika anak berkebutuhan khusus tetap dibiarkan sekolah di Luar Biasa atau SLB (Sekolah Segregasi), mereka hanya bersosialisasi dengan teman yang mempunyai hambatan yang sama, sehingga dari segi pemikiran tidak dapat berkembang.

Ketiga, "derajat perubahan yang diinginkan"

Kebijakan yang termuat dalam Peraturan Gubernur Jawa Timur Nomor 6 Tahun 2011 tentang 
Penyelenggaraan Pendidikan Inklusif sebenarnya sama seperti Peraturan Menteri Pendidikan Nasional Republik Indonesia Nomor 70 Tahun 2009 tentang Pendidikan Inklusif bagi Peserta Didik yang Memiliki Kelainan dan Memiliki Potensi Kecerdasan dan / atau Bakat Istimewa. Peraturan Gubernur Jawa Timur Nomor 6 Tahun 2011 hanya menimbang bahwa untuk melaksanakan ketentuan dalam Pasal 6 Peraturan Menteri Pendidikan Nasional Republik Indonesia Nomor 70 Tahun 2009 tentang Pendidikan Inklusif bagi Peserta Didik yang Memiliki Kelainan dan Memiliki Potensi Kecerdasan dan / atau Bakat Istimewa, maka perlu mengatur Penyelenggaraan Pendidikan Inklusif Provinsi Jawa Timur dengan Peraturan Gubernur Jawa Timur.

Dengan dibentuknya Peraturan Gubernur Jawa Timur Nomor 6 Tahun 2011 perubahan yang diharapkan yaitu mampu untuk memberikan layanan mutu pendidikan yang berkualitas bagi anak berkebutuhan khusus melalui penyelenggaraan pendidikan inklusif Karena sebelum adanya peraturan Peraturan Gubernur Jawa Timur Nomor 6 Tahun 2011 ini layanan yang diberikan peserta didik anak berkebutuhan khusus sangat terbatas, karena terkendalanya tenaga, ilmu serta ketrampilan yang dimiliki oleh tenaga pendidik pelaksanaan pendidikan inklusif tidak berjalan efektif.

Keempat "letak pengambilan keputusan"

Penyelenggaraan pendidikan inklusif dapat dilaksanakan pada lembaga pendidikan di semua jenjang sekolah PAUD, TK/SD/SMP/SMA dan SMK yang berada dibawah naungan Kementrian Pendidikan Nasional dan Kebudayaan serta juga dapat diselenggarakan oleh kelompok belajar, RA/BA, MI/MTs dan SMA yang berada dibawah naungan Kementrian Agama. Dalam hal ini, Peraturan Gubernur Jawa Timur Nomor 6 Tahun 2011 tentang penyelenggaraan pendidikan inklusif merupakan kebijakan yang dilaksanakan berada dibawah naungan Kementrian Pendidikan Nasional dan Kebudayaan, pembinaan penyelenggaraan pendidikan inklusif di tingkat Daerah/Provinsi dilaksanakan oleh Dinas Pendidikan dan KebudayaanProvinsi Jawa Timur, kemudian diturunkan ke Dinas Pendidikan dan Kebudayaan Kota Surabaya sebagai pembinaan penyelenggaraan pendidikan inklusif di tingkat Kota.

\section{Kelima“ pelaksanaan program"}

Peraturan Gubernur Jawa Timur Nomor 6 Tahun 2011 merupakan sebuah kebijakan yang mengatur tentang penyelenggaraan pendidikan inklusif, supaya program pendidikan inklusif dapat berjalan sesuai dengan tujuan, maka dibutuhkannya implementor dalam pelaksanaan program pendidikan inklusif. Dalam hal ini jumlah guru pendidik khusus dari PLB ada 1 orang, kemudian jumlah guru mata pelajaran yang mendapatkan pelatihan ada 75 orang, jumlah tim pengembang inklusi ada 5 orang, jumlah peserta didik berkebutuhan khusus ada 60 siswa dan siswa reguler kurang lebih ada 900 anak terbagi menjadi 28 kelas. Implementor yang terlibat dalam implementasi kebijakan program pendidikan inklusif ini sudah memiliki tugas dan fungsi masing-masing.

\section{Keenam "Sumber daya yang dilibatkan"}

Variabel sumber daya merupakan sumber daya yang digunakan untuk mendukung pelaksanaan sebuah kebijakan agar berjalan secara efektif. Sumber daya yang dialokasikan dalam implementasi sebuah kebijakan adalah sumber daya manusia dan non-manusia. Sumber daya manusia yang dialokasikan untuk kebijkan Peraturan Gubernur Jawa Timur Nomor 6 Tahun 2011 dalam pelaksanaan program pendidikan inklusif pada satuan pendidikan yaitu meliputi : a) Guru kelas dan Guru mata pelajaran b) Guru pendidik khusus c) Tenaga Kependidikan lain dan Profesional lain Psikolog, Bimbingan Konseling, terapis -Tenaga medis/paramedis. Dalam hal ini, sumber daya manusia yang dialokasikan dalam pelaksanaan program pendidikan inklusi di enam lembaga sekolah inklusi meliputi, semua guru mata pelajaran, b) Guru pendidik khusus : 6 0rang, c) Team khusus Inklusi 27 Orang, d) Tenaga kependidikan lain dan profesioanal lain; Psikolog dari Unair, Pendidikan Luar Biasa dari Unesa, Tenaga medis dari Unair.

Sedangkan untuk tenaga pekerja sosial pendidikan, dan tenaga terapis belum dialokasikan. Selain itu juga untuk tenaga Guru Pendidik Khusus di masing-masing sekolah penyelenggara hanya ada satu orang yang dirasa sangat kurang, karena jumlah guru pendidik khusus tidak sebanding dengan jumlah peserta didik berkebutuhan khusus yang ada 60 siswa. Sumber daya non-manusia yang dialokasikan dalam kebijakan ini adalah sumber daya anggaran dan sumber daya peralatan. Pengelolaan pembiayaan pendidikan yang dialokasikan pada sekolah penyelenggara pendidikan inklusif dapat bersumber dari dana pemerintah APBN dan APBD sesuai anggaran pendidikan yang berlaku. Dana tersebut dapat berupa BSM dan BOP, bantuan yang diberikan oleh pemerintah pusat kepada Jawa Timur yang pertama yaitu BSM, pemerintah mengalokasikan anggaran pada tahun 2013 untuk penyelenggaraan pendidikan inklusif masing-masing siswa berkebutuhan khusus mendapat bantuan sebesar Rp. 1.150.000, bantuan tersebut diberikan pihak sekolah untuk memenuhi kebutuhan setiap siswa berkebutuhan khusus. Bantuan yang kedua yaitu BOP, pemerintah mengalokasikan anggaran pada 
tahun 2013 untuk pendidikan inklusi masing-masing sekolah mendapat bantuan sebesar Rp. 35.000.000.

Selain bantuan dari pemerintah pusat, penyelenggaraan pendidikan inklusif juga mendapat bantuan dari pemerintah daerah Jawa Timur yang bersumber dari APBD. Pemprov JATIM mengalokasikan anggaran untuk penyelenggaraan pendidikan inklusif di Jawa Timur setiap sekolah diberikan bantan sebesar Rp. 10.000.000. Sumber daya peralatan yang dialokasikan dalam pelaksanaan program pendidikan inklusif sudahterpenuhi sesuai dengan karakter masing-masing peserta didik Dari variabel lingkungan implementasi mencakup beberapa sub variabel, pertama "Kekuasaan, kepentingan, strategi aktor yang terlibat" Dalam mengimplementasikan penyelenggaraan pendidikan inklusif.

Dinas Pendidikan dan Kebudayaan Kota Surabaya memegang kekuasaan penuh atas penyelenggaraan pendidikan inklusif ini. Dinas Pendidikan dan Kebudayaan Kota Surabaya merupakan pembina penyelenggaraan pendidikan inklusif ditingkat Kota. Sehingga dapat diketahui bahwa kekuasaan berada pada Dinas Pendidikan dan Kebudayaan Kota Surabaya dalam hal mengambil suatu keputusan maupun kebijakan. Sedangkan untuk kegiatan secara teknis lapangan kewenangan atau kekuasaan penuh ada pada Kepala Sekolah, karena Kepala Sekolah mengetahui secara langsung kondisi di lapangan. Berdasarkan pemaparan tersebut dapat diketahui bahwa untuk mengambil sebuah keputusan maupun kebijakan, kekuasaan berada pada Dinas Pendidikan dan Kebudayaan Kota Surabaya.

Untuk mencapai keberhasilan suatu kebijakan maka diperlukannya kajian mengenai kepentingan dalam lingkungan implementor. Setiap implementor mempunyai kekuasaan yang berbeda, hal ini yang menyebabkan kajian kepentingan dalam suatu lingkungan implementor itu penting.Kepentingan dari setiap implementor dalam penyelenggaraan pendidikan inklusif ini adalah untuk mengimplementasikan kebijakan Peraturan Gubernur Jawa Timur Nomor 6 Tahun 2011 Tentang Penyelenggaran Pendidikan Inklusif agar implementasi ini dapat berhasil, memberikan layanan penuh dan dirasakan oleh semua peserta didik berkebutuhan khusus dalam akses pendidikan tanpa adanya diskriminasi. Pada dasarnya agar kebijakan yang dilaksanakan bisa berhasil dengan baik, yaitu dengan memberikan kesempatan kepada semua peserta didik yang memiliki kelainan dan miliki potensi kecerdasan yang istimewa untuk mengikuti pendidikan atau pembelajaran dalam lingkungan pendidikan secara bersama-sama dengan peserta didik pada umumnya.

Penyelenggaraan pendidikan inklusif ini juga mendapatkan respon positif dari target group yaitu peserta didik berkebutuhan khusus mengalami peningkatan setiap tahunnya untuk menerima siswa berkebutuhan khusus. Hasil mewawanca dengan salah satu siswa berkebutuhan khusus, siswa berkebutuhan khusus ini merasa lebih senang bersekolah di sekolah inklusi, karena mereka lebih mempunyai banyak teman dan bisa menambah wawasan pengetahuan. Berdasarkan pernyataan tersebut, menunjukkan bahwa siswa berkebutuhan khusus mendukung dalam ketercapaian tujuan dari kebijakan Peraturan Gubernur Jawa Timur Nomor 6 Tahun 2011 tentang Penyelenggaraan Pendidikan inklusif. Oleh karena itu, kepentingan para pelaku kebijakan yang terlibat menunjukkan kepentingan yang sama, yaitu untuk mensuskeskan program pendidikan inklusi supaya siswa berkebutuhan khusus mendapatkan pendidikan yang layak. Sehingga kebijakan ini tercapai sesuai dengan tujuan.

Pembahasan

Kebijakan publik merupakan suatu tindakantindakan, kegiatan-kegiatan atau peraturan-peraturan yang dibuat oleh baik pejabat pemerintah maupun sekelompok masyarakat yang memiliki tujuan yang jelas sebagai upaya untuk memecahkan permasalahan dari berbagai aspek kehidupan masyarakat dan memiliki unsur untuk mewujudkan kepentingan publik.Kebijakan yang dikeluarkan oleh Pemerintah Provinsi Jawa Timur salah satunya yaitupenyelenggaraan pendidikan inklusif, pendidikan inklusif merupakan salah satu kebijakan yang dikeluarkan oleh Gubernur Jawa Timur untuk meningkatkan kualitas mutu pendidikan anak berkebutuhan khusus dengan memberikan kesempatan dapat mengikuti pendidikan atau pembelajaran dalam lingkungan pendidikan secara bersama-sama dengan peserta didik pada umumnya. Program ini dibuat karena pendidikan anak berkebutuhan khusus selama ini kurang diperhatikan dan lokasi tempat belajar dibedakan dari peserta didik pada umumnya,sehingga perlu diimplementasikannya program pendidikan inklusif untuk anak berkebutuhan khusus agar tidak menciptakan pendidikan yang diskriminasi.

Implementasi merupakan suatu kajian mengenai studi kebijakan yang mengarah pada proses pelaksanaan dari suatu kebijakan. Dalam praktiknya implementasi kebijakan merupakan suatu proses yang sangat penting. Dimana para pelaksana kebijakan dapat mengetahui apakah program yang dibuat berhasil/tidak dalam mencapai tujuan yang telah direncanakan. Dalam hal ini Pemerintah Provinsi Jawa Timur melaksanakan sebuah kebijakan yaitu Peraturan Gubernur Jawa Timur Nomor 6 Tahun 2011 tentang Penyelenggaraan Pendidikan inklusif. Ketika mengimplementasikan Peraturan Gubernur Jawa Timur Nomor 6 Tahun 2011 tentang Penyelenggaraan Pendidikan Inklusif tersebut, maka 
diperlukan suatu tahapan-tahapan yang sistematis dalam proses implementasi, beberapa tahapan diantaranya yaitu tahap interprestasi, pengorganisasian dan aplikasi. Pada tahap interprestasi ini kebijakan tentang pendidikan inklusif diwujudkan dalam bentuk Peraturan Gubernur (Pergub) yang dibuat berdasarkan melaksanakan ketentuan dalam Pasal 6 Peraturan Menteri Pendidikan Nasional Nomor 70 tahun 2009 tentang Pendidikan Inklusif. Pada tahap pengorganisasian ini mengarah pada proses kegiatan mengatur dan menetepkan siapa yang menjadi pelaksana kebijakan, penetapan anggaran dan penetapan sarana-prasarana, penetapan tata kerja (juklak dan juknis), dan penetapan manajemen pelaksanaan kebijakan.

Kebijakan tersebut dilaksanakan oleh Dinas Pendidikan dan Kebudayaan Kota Surabaya dan oleh Kepala Sekolah di enam Lembaga yang menyelenggarakan Pendidikan Inklusif sebagai tempat pelaksanaan program pendidikan inklusif. Sumber daya keuangan dan peralatan yang dibutuhkan dalam penyelenggaraan pendidikan inklusif dari APBN dan APBD. Penetapan tata kerja dibuat oleh Dinas Pendidikan dan Kebudayaan Provinsi Jawa Timur.

Para pelaksana kebijakan tersebut memiliki peran masing-masing dalam mengimplementasikan program pendidikan inklusif. Kedua unsur program, program yang dilaksanakan yaitu program pendidikan inklusif yang bertujuan untuk memberikan kesempatan kepada semua peserta didik berkebutuhan khusus untuk memperoleh pendidikan yang bermutu sesuai dengan kemampuannya. Ketiga unsur target group/kelompok sasaran, kelompok sasaran program yaitu tuna netra, tuna rungu, tuna wicara, tuna grahita, tuna daksa, tuna laras, berkesulitan belajar, autis, berbakat istimewa. Setelah unsur-unsur implementasi telah disediakan, maka langkah selanjutnya dilakukan adalah mengimplementasikan kebijakan.

Kebijakan Peraturan Gubernur Jawa Timur Nomor 6 Tahun 2011 bertujuan untuk memberikan kesempatan kepada semua peserta didik yang memiliki kelainan fisik, emosional, mental, dan sosial atau memiliki potensi kecerdasan dan/atau bakat istimewa untuk memperoleh pendidikan yang bermutu sesuai dengan kebutuhan dan kemampuannya. Serta mewujudkan penyelenggaraan pendidikan yang menghargai keanekaragam, dan tidak diskriminatif bagi semua peserta didik berkebutuhan khusus.

Berdasarkan tujuan kebijakan tentang penyelenggaraan pendidikan inklusif, maka dapat dilihat bahwa kebijakan Peraturan Gubernur jawa Timur Nomor 6 Tahun 2011 berusaha memenuhi kepentingan anak berkebutuhan khusus dengan memberikan kesempatan kepada semua peserta didik yang memiliki kelainan atau bakat istimewa untuk mengikuti pendidikan atau pembelajaran dalam lingkungan pendidikan secara bersama-sama dengan peserta didik pada umumnya di sekolah reguler. Selain itu juga dalam sekolah inklusi memberikan layanan pendidikan yang bermutu sesuai dengan hambatan yang dimiliki anak berkebutuhan khusus dengan mengunakan Kurikulum Modifikasi. Kurikulum Modifikasi merupakan kurikulum yang sama dengan standart peserta didik pada umunya, hanya saja dalam kurikulum ini guru melakukan modifikasi pada strategi pembelajaran sesuai dengan kebutuhan dan kemampuan peserta didik berkebutuhan khusus. Selain dengan menerapkan Kurikulum Modifikasi, kepentingan anak berkebutuhan khusus juga terpenuhi melalui Program Pembelajaran Individual (PPI), dengan bantuan PPI, siswa berkebutuhan khusus secara bertahap dapat menunjukkan peningkatan kemampuan belajar melalui pendekatan, perhatian, cara, dan tindakan tertentu. Dalam hal ini, kebijakan Peraturan Gubernur Jawa Timur Nomor 6 Tahun 2011 tentang Penyelenggaraan Pendidikan Inklusif dirasa memenuhi kepentingan sesuai yang dibutuhkan anak berkebutuhan khusus.

Ketika sebelum diimplementasikan kebijakan Peraturan Gubernur Jawa Timur Nomor 6 Tahun 2011 ini, kebijakan Peraturan Menteri Pendidikan Nasional RI Nomor 70 Tahun 2009 program pendidikan inklusif belum bisa dirasakan oleh semua anak berkebutuhan khusus di wilayah Provinsi Jawa Timur. Oleh karena itu, Peraturan Gubernur Jawa Timur No.6 Tahun 2011 diterbitkan sebagai bentuk komitmen Pemerintah Jawa Timur untuk menjamin penyelenggaraan pendidikan inklusif di Jawa Timur. Dengan adanya program pendidikan inklusif ini diharapkan mampu untuk memberikan kualitas mutu pendidikan yang layak bagi anak berkebutuhan khusus.

\section{PENUTUP}

\section{Simpulan}

Implementasi Program Pendidikan dikaji berdasarkan dari dua variabel menurut Merilee $S$. Grindle, dua variabel tersebut antara lain variabel Isi Kebijakan dan Lingkungan Implementasi. Hasil dan pembahasan penelitian ditemukannya beberapa masalah dalam mengimplementasikan program pendidikan inklusif, akan tetapi permasalahan tersebut tidak menghambat jalannya proses implementasi. hasil penelitian menunjukkan bahwa implementasi program pendidikan inklusif telah berjalan dengan baik sesuai dengan target sasaran yang hendak dicapai.

Kepentingan anak berkebutuhan khusus dalam pelaksanaan Peraturan Gubernur Jawa Timur Nomor 6 Tahun 2011 tentang Penyelenggaraan Pendidikan 
Inklusif sudah terpenuhi. Wujudnya memberikan kesempatan kepada anak berkebutuhan khusus untuk mengikuti pembelajaran dalam lingkungan pendidikan secara bersama-sama dengan peserta didik pada umumnya.

Pelaksanaan Peraturan Gubernur Jawa Timur No. 6 Tahun 2011 tentang Penyelenggaraan Pendidikan Inklusif memberikan dampak positif terhadap anak berkbutuhan khusus. Manfaat yang diterima yaitu ketika anak berkebutuhan khusus bersekolah di sekolah inklusif, maka anak tersebut dapat bersosialisasi dengan peserta didik pada umumnya. Program yang diberikan oleh sekolah dalam penyelenggaraan pendidikan inklusif juga memberikan manfaat agar anak berkebutuhan khusus dapat hidup lebih mandiri dan lebih baik dari sebelumnya.

Perubahan yang telah dicapai dengan terlaksananya kebijakan Peraturan Gubernur Jawa Timur Nomor 6 Tahun 2011 adalah menjamin terselenggaranya pendidikan inklusif sesuai dengan kebutuhan masingmasing peserta didik berkebutuhan khusus. Dibentuknya kebijakan Peraturan Gubernur Jawa Timur No. 6 Tahun 2011 diharapkan bagi sekolah-sekolah umum dapat menerima peserta didik berkebutuhan khusus untuk memberikan kesempatan kepada anak berkebutuhan khusus belajar bersama-sama dengan peserta didik pada umumnya. Hal ini dikarenakan pendidikan bagi anak berkebutuhan khusus selama ini kurang diperhatikan dan lokasi pendidikan untuk anak berkebutuhan khusus dibedakan dengan peserta didik pada umumnya. Oleh karena itu, agar tidak menciptakan pendidikan yang diskriminasi, maka dibentuklah penyelenggaran pendidikan inklusif. kenyataan di lapangan menunjukkan bahwa ke enam Lembaga penyelenggara kebijakan (3 SDN dan 3 SMPN) menerima anak berkebutuhan khusus untuk mengikuti pembelajaran bersama-sama dengan siswa reguler.

Pembinaan penyelenggaraan pendidikan inklusif tepat berada di Dinas Pendidikan dan Kebudayaan Kota Surabaya. Sehingga letak program pendidikan inklusif dinilai sudah tepat dan efektif. Sumber daya yang dialokasikan dalam pelaksanaan Peraturan Gubernur Jawa Timur Nomor 6 Tahun 2011 tentang Penyelenggaraan Pendidikan Inklusif yaitu sumber daya manusia dan non-manusia. Dalam pelaksanaan implementasi program pendidikan inklusif di Surabaya mengalami kendala dari segi sumber daya manusia, yaitu kurangnya guru pendidik khusus, tidak tersedianya tenaga Bimbingan Konseling, serta tidak tersedianya tenaga terapis. Oleh karena itu, perlu segera dialokasikan sumber daya manusia yang belum tersedia agar proses pembelajaran dapat berjalan secara maksimal. Dari segi sumber daya non-manusia tidak mengalami kendala.
Sumber daya non-manusia dibagi menjadi dua yaitu dana dan peralatan. Sumber dana yang digunakan dalam pelaksanaan program pendidikan inklusi yaitu dari dana APBN dan APBD. Kemudian Peralatan yang dibutuhkan peserta didik berkebutuhan khusus sudah terpenuhi sesuai dengan karakter anak berkebutuhan khusus.

\section{Saran}

1. Diharapkan para pelaksana kebijakan terus melakukan pembinaan atau pelatihan kepada pendidik untuk menambah wawasan dan ilmu pengetahuan mengenai penyelenggaraan pendidikan inklusif.

2. Diharapkan para pelaksana kebijakan terus melakukan sosialisasi kepada masyarakat tertakait penyelenggaraan pendidikan inklusifagar program tersebut dapat diketahui dan dirasakan oleh semua anak berkebutuhan khusus.

3. Perlu ditambah lagi tenaga guru pendidik khusus serta perlu dialokasikannya tenaga, tenaga bimbingan konseling dan tenaga terapis untuk penyelenggaraan pendidikan inklusif.

\section{DAFTAR PUSTAKA}

Agustino, Leo. 2012. Dasar-Dasar Kebijakan Publik.Bandung: CV. Alvabeta.

Dunn, William N. 2000. Pengantar Analisis Kebijakan Publik. Yogyakarta: Gadjah Mada University Press. Geniofam. 2010.

Peraturan Gubernur Jawa Timur Nomor 6 Tahun 2011 tentang Penyelenggaraan Pendidikan Inklusif Provinsi Jawa Timur.

Peraturan Menteri Pendidikan Nasional Republik Indonesia Nomor 70 Tahun 2009 tentang pendidikan inklusif bagi peserta didik yang memiliki kelainan dan memiliki potensi kecerdasan dan/atau bakat istimewa.

Petunjuk Teknis Penyelenggaraan Pendidikan Inklusif Dinas Pendidikan dan Kebudayaan Provinsi Jawa Timur tahun 2011.

Smart, Aqila. 2010. Anak Cacat Bukan Kiamat : Metode Pembelajaran \& Terapi Untuk Anak Berkebutuhan Khusus. Yogyakarta : katahati.

Subarsono. 2008. Analisis Kebijakan Publik : Konsep, Teori Dan Aplikasi. Yogyakarta : Pustaka Pelajar.

Sugiyono. 2012. Metode Penelitian Administrasi: Dilengkapi Dengan Metode R\&D. Bandung: CV. Alfabeta. 
Tachjan. 2006. Implementasi Kebijakan Publik. Bandung: AIPI

Widodo, Joko. 2011. Analisis Kebijakan Publik: Konsep dan Aplikasi Analisis Proses Kebijakan Publik. Malang: Bayumedia Publishing.

Winarno, Budi. 2008.Kebijakan Publik: Teori Dan Proses. Yogyakarta: Media Pressindo.

Grindle, Merilee S. 1980. Politics and Policy Implementation in The Third World, Princnton University Press, New Jersey.

Ormrod, Jeanne Ellis, 2008. Psikologi Pendidikan Jilid I. Jakarta : Penerbit Erlangga.

Miles, Mattew B dan A. Michael Huberman. 2007. Analisis Data Kualitatif Buku Sumber tentang Metode-Metode Baru. Jakarta: Univ. Indonesia Press.

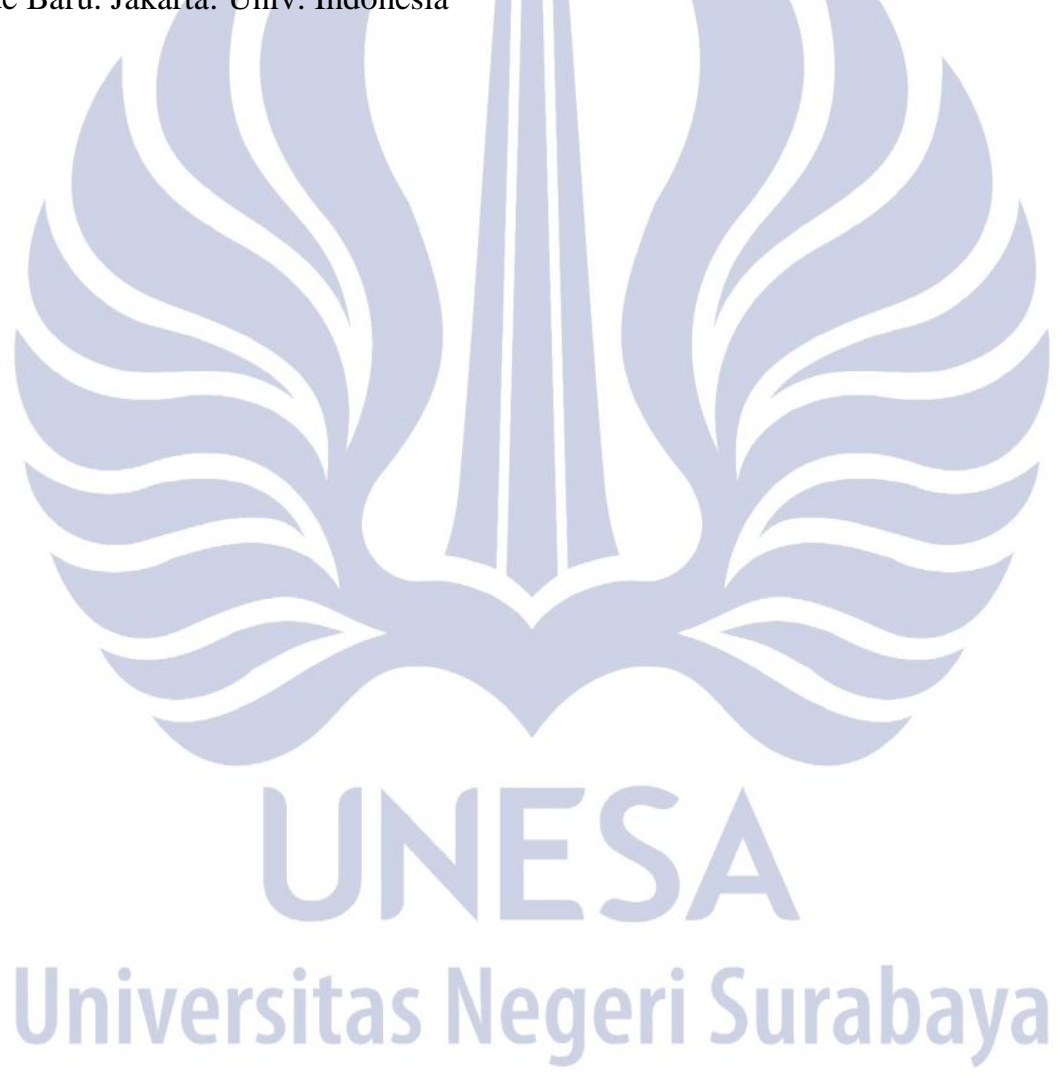

